\title{
GROWTH AND QUALITY RESPONSES OF TALL FESCUE (Festuca arundinacea Schreb.) TO DIFFERENT IRRIGATION LEVELS AND NITROGEN RATES
}

\author{
Burak Nazmi CANDOGAN ${ }^{*}$, Ugur BILGILI ${ }^{2}$, Senih YAZGAN ${ }^{1}$, Esvet ACIKGOZ \\ ${ }^{1}$ Uludag University, Faculty of Agriculture, Department of Biosystems Engineering, Bursa-TURKEY \\ ${ }^{2}$ Uludag University, Faculty of Agriculture, Department of Field Crops, Bursa-TURKEY \\ *Corresponding author: bncandogan@uludag.edu.tr
}

Received : 26.03.2013

\begin{abstract}
A 2-year experiment was conducted to investigate the effects of different irrigation levels and nitrogen rates on visual turfgrass colour and quality and clipping yield of tall fescue (Festuca arundinacea Schreb.) under subhumid climatic conditions. The treatments consisted of five levels of irrigation, $25 \%\left(I_{1}\right), 50 \%\left(I_{2}\right), 75 \%\left(I_{3}\right)$, $100 \%\left(I_{4}\right)$ and $125 \%\left(I_{5}\right)$, of the evaporation measured from a Class A pan and two rates of nitrogen, $25 \mathrm{~kg} \mathrm{~N}$ $\mathrm{ha}^{-1}\left(N_{1}\right)$ and $50 \mathrm{~kg} \mathrm{~N} \mathrm{ha}^{-1}\left(N_{2}\right)$. The $\mathrm{N}$ rates were applied as a monthly rate during growing seasons (MaySeptember). The experimental area was irrigated by a pop-up sprinkler irrigation system. The irrigation was applied at 3-day intervals during May-September for both years. The seasonal crop evapotranspiration $\left(\mathbf{E T}_{\mathrm{c}}\right)$ under the treatments ranged from 315 to $1154 \mathrm{~mm}$ in 2007 and from 363 to $1100 \mathrm{~mm}$ in 2008. The ETc increased with increasing the both $\mathrm{N}$ rate and irrigation level, and the best seasonal turf quality of tall fescue was obtained for the $I_{4}$ and $I_{5}$ treatments under $N_{2}$ rate. This study demonstrated that, when the level of irrigation and nitrogen rate were evaluated together, the $N_{2} I_{4}$ treatment ensured sufficiently dark turf colour and quality. Based on the results of this study, it is concluded that an acceptable turf quality can be sustained under the $N_{1} I_{1}$ treatment in May, $N_{1} I_{2}$ treatment in June, July and August and $N_{1} I_{4}$ treatment in September (or $N_{2} I_{2}$ treatment in September) according to water conservation. When rainfall amountis high (132.2 $\left.\mathrm{mm}\right)$ in September, the $N_{1} I_{1}$ treatment may sustain acceptable turf quality for this month.
\end{abstract}

Keywords : evapotranspiration, irrigation level, nitrogen rate, tall fescue, turfgrass quality.

\section{INTRODUCTION}

In regions with a sub-humid climate, the frequency and amount of rainfall during the summer season are often quite variable. Under these conditions, drought or heat stress alone causes a severe decline in the turf quality of cool-season grasses (Wehner and Watschke, 1984; Huang et al., 1998). Consequently, the dry weather and variable rain events in the summer make irrigation necessary to ensure high quality turf. Indeed, the irrigation of residential, commercial, industrial, and recreational turf areas is commonly employed to ensure acceptable turf quality (Cardenas-Lailhacar et al., 2008).

The irrigation of recreational sites or sporting areas is necessary to provide the desired functional and aesthetic properties (Kneebone et al., 1992). However, water requirements are considerable, and it is expensive to maintain a good turfgrass quality during the summer season. Therefore, prudent irrigation greatly influences both the management cost and environmental impact of turfgrasses (Cereti et al., 2009), and turfgrass scientists and managers desire to develop strategies for maintaining a certain level of turf quality while considerably reducing irrigation inputs (Ervin and Koski, 1998).

The results of studies on cool-season turfgrass evapotranspiration $\left(\mathrm{ET}_{\mathrm{c}}\right)$ showed that the $\mathrm{ET}_{\mathrm{c}}$ rates ranged from $3 \mathrm{~mm} \mathrm{~d}^{-1}$ for hard fescue (Festuca longifolia Thuill.) to $12 \mathrm{~mm} \mathrm{~d}^{-1}$ for Kentucky bluegrass (Poapratensis L.).This high variability was found to be the result of the many factors, especially the soil moisture conditions (Romero and Dukes, 2009). Deficit irrigation, which wets most of the zone where capillary roots absorb water, even though they are shallow, can conserve water by taking advantage of the tolerance of turfgrass to short periods of drought between irrigation events (Kneebone et al., 1992). 'Rebel' tall fescue visual quality was reduced by about $10 \%$ when irrigated at a deficit level of $27 \%$ of actual evapotranspiration $\left(\mathrm{ET}_{\mathrm{a}}\right)$ deficit in Colarado (Feldhake et al., 1984). In another study conducted in Colarado, tall fescue irrigated every $2 \mathrm{~d}$ at $50 \% \mathrm{ET}_{\mathrm{a}}$ exhibited only small reductions in turf quality (Fry and Butler, 1989). Qian and Engelke (1999) observed that irrigation required to maintain acceptable turf quality ranged from about $35 \%$ of evaporation from Class A pan ( $\left.E_{\mathrm{pan}}\right)$ for 'Tifway' Bermuda to $67 \% \mathrm{E}_{\mathrm{pan}}$ for 'Rebel II' tall fescue. Gibeault et 
al. (1985) reported that turf quality in blends of Kentucky bluegrass (Poa pratensis L.) and perennial ryegrass (Lolium perenne L.) cultivars, and 'Kentucky 31' tall fescue, declined slightly when irrigation was reduced by $20 \%$ of calculated ET in southern California. Tall fescue irrigated $4 \mathrm{~d}$ weekly in Nevada required $80 \%$ of calculated reference ET tomaintain cover and colour (Dean et al., 1996). Applying irrigation to $80 \%$ of field capacity reduced water use of Kentucky bluegrass by $20 \%$ and only reduced quality by $10 \%$ (Danielson et al., 1981). In Kansas, tall fescue and bermudagrass [Cynodon dactylon (L.) Pers.] maintained similar quality levels at 60 and $40 \%$ of $\mathrm{ET}_{\mathrm{a}}$, respectively, compared with the same species under full-irrigated conditions (Fu et al., 2004).

Applying nitrogen $(\mathrm{N})$ fertilizer is an integral part of turfgrass production to ensure a fast and uniform growth, an acceptable colour, a high shoot density and an adequate strength for harvesting (Beard, 1973). Furthermore, N management is an important factor in water conservation and is often overlooked (Brown et al., 2004), though most of the research investigating the influence of soil fertility on turfgrass ET has focused on N. N applied at a total of 211 and $420 \mathrm{~kg} \mathrm{~N} \mathrm{ha}^{-1}$ over 2 years increased the ET rate of a mixture of orchard grass (Dactylis glomerata L.), smooth bromegrass (Bromus inermis Leyss.), and creeping red fescue (Festuca rubra var. rubra) (Krogman, 1967). However, the water use efficiency also increased with nitrogen applications. In a greenhouse study, nitrogen-deficient 'Merion' Kentucky bluegrass used 14\% less water than turf receiving supplemental nitrogen fertilization (Sills and Carrow, 1983). Nitrogen-deficient turf also has been shown to decline more rapidly in quality when subjected to moisture stress compared to adequately fertilized turf (Feldhake, 1981).

Turf quality is of fundamental importance in turfgrass evaluation and includes aesthetic and functional aspects.
Turf colour is one of the major components of the aesthetic quality, and it is often evaluated in field studies, as it is a good indicator of water and nutrient status (Beard, 1973). The aim of this study was to determine the effects of different irrigation and nitrogen levels for maintaining acceptable turf quality of tall fescue under sub-humid climatic conditions. Such information might help turfgrass managers to sustain acceptable turf quality of tall fescue and to provide water conservation, especially in sub-humid conditions.

\section{MATERIALS AND METHODS}

The field studies were conducted on experimental turfgrass plots at the Research and Training Centre of the Agriculture Faculty, Uludag University, Bursa, Turkey $\left(40^{\circ} 15^{\prime} 29^{\prime \prime} \mathrm{N}, 2^{\circ} 53^{\prime} 39^{\prime \prime} \mathrm{E}\right.$, and altitude $\left.72 \mathrm{~m}\right)$, between May and September in 2007 and 2008. The soil of the experimental area is characterized by an average clay content of $50 \%$. The gravimetrically average field capacity (FC) was $39.1 \%$, the permanently wilting point (PWP) was $27.1 \%$, the bulk density was $1.36 \mathrm{Mg} \mathrm{m}^{-3}$, and the total available moisture (TAM) was $98.0 \mathrm{~mm}$ for a 0 $60 \mathrm{~cm}$ soil profile. The average amount of organic matter and electrical conductivity (EC) were also $0.58 \%$ and 50 $\mathrm{mS} \mathrm{m}^{-1}$, respectively. Some physical and chemical properties of the experimental site soil are given in Table 1. The region climate is temperate, the summers are hot and dry, and the winters are mild and humid (Candogan and Yazgan, 2010; Candogan et al., 2013). The long-term (1975-2003) annual rainfall, temperature and relative humidity are $675.9 \mathrm{~mm},+14.5^{\circ} \mathrm{C}$ and $66.0 \%$, respectively. According to the annual rainfall amount, climate is subhumid (from 600 to $700 \mathrm{~mm}$ of annual precipitation) (Jensen, 1980). Most of the precipitation occurs during the winter and early spring. In the study region, late spring and summer rains are limited and erratic.

Table 1. Selected measured soil properties of the experimental site.

\begin{tabular}{ccccccccccc}
\hline $\begin{array}{c}\text { Soil } \\
\text { Depth } \\
(\mathbf{c m})\end{array}$ & $\begin{array}{c}\text { Sand } \\
(\boldsymbol{\%})\end{array}$ & $\begin{array}{c}\text { Silt } \\
(\boldsymbol{\%})\end{array}$ & $\begin{array}{c}\text { Clay } \\
(\boldsymbol{\%})\end{array}$ & $\begin{array}{c}\text { Texture } \\
\text { Class }\end{array}$ & $\begin{array}{c}\text { Bulk } \\
\text { Density } \\
\left(\mathbf{M g ~ m}^{-3}\right)\end{array}$ & $\begin{array}{c}\text { Field } \\
\text { Capacity } \\
(\boldsymbol{\%})\end{array}$ & $\begin{array}{c}\text { Wilting } \\
\text { Point } \\
(\boldsymbol{\%})\end{array}$ & $\mathbf{p H}$ & $\begin{array}{c}\mathbf{E C} \\
\left(\mathbf{m S ~ m}^{-\mathbf{1}}\right)\end{array}$ & $\begin{array}{c}\text { Organic } \\
\text { Matter } \\
(\boldsymbol{\%})\end{array}$ \\
\hline $\mathbf{0 - 3 0}$ & 24.3 & 26.2 & 49.5 & Clay & 1.35 & 38.2 & 27.1 & 6.1 & 50 & 0.72 \\
$\mathbf{3 0 - 6 0}$ & 23.3 & 26.2 & 50.5 & Clay & 1.36 & 40.0 & 27.0 & 6.4 & 50 & 0.43 \\
\hline
\end{tabular}

The daily meteorological data were measured via an automated meteorological station (Watch Dog, Spectrum Technologies, Inc., Plainfield, USA) installed near the research area during experimental years. The monthly averages of meteorological data that were measured daily in the study area during the 2007 and 2008 experimental seasons are provided in Table 2. The total amount of rainfall during the 2007 and 2008 seasons were 77.1 and $180.3 \mathrm{~mm}$, respectively (Table 2).

Tall fescuecv Comfort was used as plant material.In the field trial, the treatments were arranged in a split plot design with four replications. The nitrogen rates were placed into the main plots, the irrigation levels into the subplots. The sub plot size was $1 \times 2=2 \mathrm{~m}^{2}$. The nitrogen application rates were monthly: $25 \mathrm{~kg} \mathrm{ha}^{-1}\left(N_{1}\right)$ and $50 \mathrm{~kg}$ $\mathrm{ha}^{-1}\left(N_{2}\right)$ during growing seasons (May-September) for both years. Nitrogen was applied in $33 \%$ ammoniumnitrate form. The irrigation treatments were based on US Weather Bureau Class A pan evaporation $\left(\mathrm{E}_{\mathrm{pan}}, \mathrm{mm}\right)$, and five irrigation treatments were selected as follows: $I_{1}=0.25 \mathrm{E}_{\mathrm{pan}}, I_{2}=0.50 \mathrm{E}_{\mathrm{pan}}, I_{3}=0.75 \mathrm{E}_{\mathrm{pan}}, I_{4}=$ $1.00 \mathrm{E}_{\mathrm{pan}}$ and $I_{5}=1.25 \mathrm{E}_{\mathrm{pan}}$. Irrigation treatments were applied at 3-day intervals. 
Table 2.Monthly averages of the meteorological data for the study area in 2007 and 2008.

\begin{tabular}{|c|c|c|c|c|c|c|}
\hline Year & Month & $\begin{array}{c}\text { Average } \\
\text { Temperature } \\
\left({ }^{\circ} \mathrm{C}\right)\end{array}$ & $\begin{array}{c}\text { Average Relative } \\
\text { Humidity } \\
(\%)\end{array}$ & $\begin{array}{c}\text { Average Wind } \\
\text { Speed } \\
\left(\mathrm{m} \mathrm{s}^{-2}\right)\end{array}$ & $\begin{array}{c}\text { Average Solar } \\
\text { Intensity } \\
\left(\mathbf{M J ~ m}^{-2} \text { day }^{-1}\right)\end{array}$ & $\begin{array}{c}\text { Total } \\
\text { Rainfall } \\
(\mathbf{m m})\end{array}$ \\
\hline \multirow[t]{5}{*}{2007} & May & 19.9 & 61.9 & 2.0 & 20.1 & 12.1 \\
\hline & June & 24.4 & 56.6 & 1.8 & 23.1 & 47.2 \\
\hline & July & 26.1 & 51.7 & 2.2 & 24.7 & 13.4 \\
\hline & August & 26.4 & 54.5 & 2.1 & 22.1 & 1.0 \\
\hline & September & 20.9 & 60.0 & 1.9 & 15.8 & 3.4 \\
\hline \multirow[t]{5}{*}{2008} & May & 18.0 & 61.4 & 1.7 & 19.6 & 22.1 \\
\hline & June & 23.8 & 55.1 & 2.0 & 22.1 & 28.8 \\
\hline & July & 25.1 & 51.6 & 2.2 & 23.1 & 0.2 \\
\hline & August & 26.7 & 53.4 & 2.3 & 22.6 & 0.0 \\
\hline & September & 20.4 & 70.1 & 1.7 & 14.0 & 132.2 \\
\hline
\end{tabular}

The soil was tilled, levelled, and rolled during the summer months of 2006. Prior to seeding, 200kg P ha and $100 \mathrm{~kg} \mathrm{~K} \mathrm{ha}^{-1}$ were incorporated into the seedbed. Turf grass was established on October 17, 2006 using a seeding rate of $400 \mathrm{~kg} \mathrm{ha}^{-1}$.The seeds were broadcast and top-dressed with a mixture of soil and peat and were irrigated as necessary to keep the soil surface moist until complete seedling emergence. The experimental area was irrigated by a pop-up sprinkler irrigation system, with sprinkler heads established in the corners of plots $(4 \times 4 \mathrm{~m}$ in size); a wetting pattern with an angle of $90^{\circ}$ was used for the experiment. In addition, the infiltration rate of the soils and sprinkling rate were determined as $8.0 \mathrm{~mm} \mathrm{~h}^{-1}$ and $7.5 \mathrm{~mm} \mathrm{~h}^{-1}$, respectively.

The soil water content was measured at $0.15 \mathrm{~m}$ and $0.45 \mathrm{~m}$ depths using a neutron probe (model $503 \mathrm{DR}$, Campbell Pacific Nuclear Intl., Inc., USA) prior to the irrigation applications. The soil moisture content at $0.15 \mathrm{~m}$ depth was also monitored using tensiometers. Aluminium access tubes were installed in the centre of the plots of two replicationsfor the neutron counts.

The crop evapotranspiration $\left(\mathrm{ET}_{\mathrm{c}}\right)$ was calculated as the soil water-balance residual for the time periods between the dates of two successive soil water content measurements (Jensen et al., 1990):

$\mathrm{ET}_{\mathrm{c}}=I+P+\Delta S-R-D$, where $I$ is the depth of irrigation water $(\mathrm{mm}), P$ is the precipitation $(\mathrm{mm}), \Delta S$ is the change in the soil water content $(\mathrm{mm}), R$ is the depth of runoff $(\mathrm{mm})$ and $D$ is the drainage below the root zone $(\mathrm{mm})$. For the calculation, $I$ was measured using water meters, and $P$ was observed at the meteorological station. Because the sprinkling rate did not exceed the infiltration rate, run off did not occur in the experimental plots. Doty et al. (1990) noted that a large portion of grass water uptake was at the $0-25 \mathrm{~cm}$ soil profile. Therefore, the effective rooting depth was regarded as $0.3 \mathrm{~m}$ in our calculations. In order to consider the percolation, moisture measurements related to the $0.6 \mathrm{~m}$ soil profile were used for soil water budget calculations.
The plots were mowed to a height of $4 \mathrm{~cm}$ when the plants reached a height 6 to $8 \mathrm{~cm}$. At each clipping date(on 18 May, on 15 June, on 12 July, on 20 August and on 18 September in 2007 and on 14 May, on 10 June, 17 July, 26 August and on September 24 in 2008) for each experimental season in both years, a $0.5 \mathrm{~m} \times 1.0 \mathrm{~m}$ strip was cut through the centre of each plot, removed and dried at $70^{\circ} \mathrm{C}$ for $24 \mathrm{~h}$, and then weighed according to Bilgili and Acikgoz (2005) and Bilgili et al. (2011).During each experimental season, visual turfgrass colour ratings were obtained on each clipping date prior to mowing. A scale of 1 to 9 was employed in which $1=$ completely yellow and 9 = dark green (Karcher and Richardson, 2003, 2005). Based on the colour, density, and uniformity of the grass, the turf quality was rated at each clipping date throughout each experimental season ( $1=$ poorest; $9=$ excellent $)$. In the present study, a rating of 6.0 or higher indicated that the quality of the turf was minimally acceptable.

Turf colour, quality ratings and clipping yield values for individual dates within each month were averaged. Data were subjected to an analysis of variance. In the analysis, months were considered fixed and treated as a repeated measure were considered random. When main or interaction effects were significant $(\mathrm{P}<0.05)$, the means were separated using Fisher's least significant difference test at the 0.05 level.

\section{RESULTS AND DISCUSSION}

The total amount of water applied and the seasonal $\mathrm{ET}_{\mathrm{c}}$ determined under the irrigation and nitrogen treatments for the 2007 and 2008 experimental periods are presented in Table 3 . The applied amount of irrigation water varied between 204.8 and $1023.8 \mathrm{~mm}$ in 2007 and 175.9 and $879.4 \mathrm{~mm}$ in 2008 . The total rainfall during the 2007 season was $77.1 \mathrm{~mm}$, whereas this amount was $180.3 \mathrm{~mm}$ in 2008 . Our results showed that the amount of irrigation water applied in both years differed due to differences in the amount and distribution of rainfall between years (Tables 2 and 3). Sign et al. (2010) stated that differences in rainfall amount and distribution resulted in different irrigation need. 
Table 3.Total amount of irrigation water, rainfall and seasonal crop evapotranspiration of tall fescue in 2007 and 2008.

\begin{tabular}{|c|c|c|c|c|}
\hline Nitrogen Rates & $\begin{array}{l}\text { Irrigation } \\
\text { Levels }\end{array}$ & $\begin{array}{l}\text { Irrigation } \\
\text { Water Applied } \\
(\mathrm{mm}) \\
\end{array}$ & $\begin{array}{l}\text { Rainfall } \\
(\mathbf{m m})\end{array}$ & $\begin{array}{l}\text { Seasonal } \\
\text { Evapotranspiration } \\
(\mathrm{mm}) \\
\end{array}$ \\
\hline \multicolumn{5}{|c|}{2007} \\
\hline \multirow[t]{5}{*}{$\mathbf{N}_{1}$} & $\mathbf{I}_{1}$ & 204.8 & 77.1 & 315 \\
\hline & $\mathbf{I}_{2}$ & 409.5 & 77.1 & 499 \\
\hline & $\mathbf{I}_{3}$ & 614.3 & 77.1 & 718 \\
\hline & $\mathbf{I}_{4}$ & 819.0 & 77.1 & 939 \\
\hline & $\mathbf{I}_{5}$ & 1023.8 & 77.1 & 1118 \\
\hline \multirow[t]{5}{*}{$\mathbf{N}_{2}$} & $\mathbf{I}_{1}$ & 204.8 & 77.1 & 340 \\
\hline & $\mathbf{I}_{2}$ & 409.5 & 77.1 & 533 \\
\hline & $\mathbf{I}_{3}$ & 614.3 & 77.1 & 755 \\
\hline & $\mathbf{I}_{4}$ & 819.0 & 77.1 & 978 \\
\hline & $\mathbf{I}_{5}$ & 1023.8 & 77.1 & 1154 \\
\hline \multicolumn{5}{|c|}{2008} \\
\hline \multirow[t]{5}{*}{$\mathbf{N}_{1}$} & $\mathbf{I}_{1}$ & 175.9 & 180.3 & 363 \\
\hline & $\mathbf{I}_{2}$ & 351.8 & 180.3 & 555 \\
\hline & $\mathbf{I}_{3}$ & 527.6 & 180.3 & 722 \\
\hline & $\mathbf{I}_{4}$ & 703.5 & 180.3 & 889 \\
\hline & $\mathbf{I}_{5}$ & 879.4 & 180.3 & 1065 \\
\hline \multirow[t]{5}{*}{$\mathbf{N}_{2}$} & $\mathbf{I}_{1}$ & 175.9 & 180.3 & 403 \\
\hline & $\mathbf{I}_{2}$ & 351.8 & 180.3 & 594 \\
\hline & $\mathbf{I}_{3}$ & 527.6 & 180.3 & 754 \\
\hline & $\mathbf{I}_{4}$ & 703.5 & 180.3 & 941 \\
\hline & $\mathbf{I}_{5}$ & 879.4 & 180.3 & 1100 \\
\hline
\end{tabular}

Based on the soil water content, irrigation water amounts, and precipitation data, the seasonal $\mathrm{ET}_{\mathrm{c}}$ values were calculated to be ranged from $315 \mathrm{~mm}$ to $1154 \mathrm{~mm}$ in 2007 and from $363 \mathrm{~mm}$ to $1100 \mathrm{~mm}$ in 2008. In a 2-year study, for cool-season turfgrass irrigated at a level of $100 \%$ of the Class A pan evaporation, Meyer and Gibeault (1986) applied $1097 \mathrm{~mm}$ of irrigation water in the first year and $983 \mathrm{~mm}$ in the second year, whereas they applied $864 \mathrm{~mm}$ in the first year and $838 \mathrm{~mm}$ in the second year using warm-season turfgrass. Under Mediterranean climatic conditions, Bastug and Buyuktas (2003) reported that the total amount of water applied and the total ET of golf course turfgrass were found as $780.3 \mathrm{~mm}$ and 896 $\mathrm{mm}$, respectively, under an irrigation treatment in which $\mathrm{k}_{\mathrm{p}}$ was set to 1.00 . In a Mediterranean climate, Emekli et al. (2007) found that the total irrigation water and amount of seasonal water used for bermudagrass at $100 \%$ of the Class A pan were $1168.2 \mathrm{~mm}$ and $1186 \mathrm{~mm}$, respectively. Although our study was conducted under a sub-humid climatic condition, the applied irrigation water and $\mathrm{ET}_{\mathrm{c}}$ values were close to the values obtained in studies conducted under arid climatic conditions. The reason for this result was due to the longer irrigation period in our study, which was a month longer than the studies of Bastug and Buyuktas (2003) and Emekli et al. (2007).

The seasonal $\mathrm{ET}_{\mathrm{c}}$ increased with the increase at $\mathrm{N}$ rate and irrigation level (Table 3). Barton et al. (2009) reported that increasing the $\mathrm{N}$ application rate increased the evapotranspiration of Kikuyu turfgrass [Pennisetum clandestinum (Hochst. ex Chiov)] under a Mediterranean- type climate. The water use by turfgrass increases as nitrogen fertilization rate increases due to the increased growth stimulated by the fertilizer (Carrow and Duncan, 2003). Additionally, in Nevada, Devitt et al. (1992) found differences in ET rate of bermudagrass between a park site and two golf course sites, which was attributed to cultural management, in particular fertilizer input. Some researchers have reported that decreasing the $\mathrm{N}$ fertilizer rate can reduce turfgrass ET under a nonlimiting water supply; however, these studies have not always included quantitative information on how the $\mathrm{N}$ rate has also affected the turfgrass quality (Shearman and Beard, 1973; Feldhake et al., 1983). As a consequence, the extent of the water savings by adjusting the $\mathrm{N}$ fertilizer rates has not necessarily been clear. Notably, Ebdon et al. (1999) demonstrated that, although decreasing the $\mathrm{N}$ fertilizer rate decreased the ET of Kentucky bluegrass, the effect was not significant within the range of the $\mathrm{N}$ fertilizer rates that are required to maintain the turfgrass with acceptable quality. Including measures of turfgrass quality is essential for assessing the extent to which the adjustment of $\mathrm{N}$ fertilizer rates can be used as a means of decreasing turfgrass water use.

Visual turfgrass colour and quality and clipping yield were significantly affected by the $\mathrm{N}$ rates, irrigation levels and monthsduring the 2007 and 2008 experimental seasons. Additionally, all two- and three-factor interactions were significant in both years, with few exceptions. The data were analyzed separately for each year regardless of the effect of the year (Table 4). 
Table 4. Results of the variance analysis of tall fescue colour, quality and clipping yield under different nitrogen rates $\left(\mathrm{NR}, \mathrm{kg}\right.$ ha $\left.{ }^{-1}\right)$, irrigation levels (IL, \%) and months (M) in the 2007 and 2008 experimental seasons.

\begin{tabular}{|c|c|c|c|c|c|c|}
\hline \multirow{2}{*}{$\begin{array}{l}\text { Variation } \\
\text { sources }\end{array}$} & \multicolumn{3}{|c|}{2007} & \multicolumn{3}{|c|}{2008} \\
\hline & Colour & Quality & $\begin{array}{l}\text { Clipping } \\
\text { Yield } \\
\end{array}$ & Colour & Quality & $\begin{array}{l}\text { Clipping } \\
\text { Yield } \\
\end{array}$ \\
\hline BLOCK & $0.6000^{\mathrm{ns}}$ & $7.4666^{\mathrm{ns}}$ & $0.9819^{\mathrm{ns}}$ & $2.3065^{\mathrm{ns}}$ & $1.5272^{\mathrm{ns}}$ & $1.0175^{\mathrm{ns}}$ \\
\hline NR & $27.2997^{*}$ & $55.9249^{* * *}$ & $68.4429^{* *}$ & $61.4990^{* *}$ & $18.3956^{*}$ & $128.2527^{* *}$ \\
\hline IL & $48.7771^{* *}$ & $103.2508^{* *}$ & $116.9202^{* * *}$ & $26.0323^{* *}$ & $36.7872^{* *}$ & $40.7112^{* *}$ \\
\hline M & $54.3451^{* *}$ & $34.1386^{* *}$ & $106.8419^{* * *}$ & $36.7983^{* *}$ & $59.0692^{* *}$ & $77.1116^{* *}$ \\
\hline $\mathbf{N R} \times \mathbf{I L}$ & $1.1836^{*}$ & $1.9363^{*}$ & $5.2410^{* *}$ & $0.5807^{*}$ & $2.2647^{*}$ & $14.5671^{* *}$ \\
\hline $\mathbf{N R} \times \mathbf{M}$ & $1.7036^{*}$ & $3.1777^{*}$ & $5.8940^{* *}$ & $1.2172^{*}$ & $1.6336^{*}$ & $15.7278^{* *}$ \\
\hline $\mathbf{I L} \times \mathbf{M}$ & $19.1485^{* *}$ & $9.0140^{* *}$ & $9.3098^{* *}$ & $12.2354^{* *}$ & $16.2685^{* *}$ & $6.6164^{* *}$ \\
\hline $\mathbf{N R} \times \mathbf{I L} \times \mathbf{M}$ & $0.8971^{\mathrm{ns}}$ & $2.7700^{* *}$ & $3.1361^{* *}$ & $3.4026^{* *}$ & $1.1113^{\mathrm{ns}}$ & $2.9932^{* *}$ \\
\hline
\end{tabular}

NR: nitrogen rates, IL: irrigation levels, M: Months, ns: not significant, " : significant at $P<0.05,{ }^{* *}$ : significant at $P<0.01$.

All of the measured parameters were affected by the $\mathrm{N}$ rates, irrigation levels and months (Table 5). The $\mathrm{N}$ rates greatly affected all of the turf responses (colour, quality, and clipping yield) and the differences were found statistically significant between the $\mathrm{N}$ rates. However, for both experimental years, these differences were not large for any of the parameters measured. Overall, the $N_{2}(50 \mathrm{~kg}$ $\mathrm{N} \mathrm{ha}{ }^{-1}$ ) treatment produced higher valuesfor turf colour and quality and clipping yields than the $N_{1}\left(25 \mathrm{~kg} \mathrm{~N} \mathrm{ha}^{-1}\right)$ treatment. In this study, the $N_{2}$ rates resulted in a darkgreen and high-quality turf and provided the highest clipping yields throughout both of the seasons; in contrast, the $N_{1}$ rates produced the lowest ratings of turf colour and quality and the lowest clipping yields. Bilgili and Acikgoz (2011) reported that increasing the rate of $\mathrm{N}$ application consistently enhanced the colour, quality ratings and clipping yields of the turf.

Table 5. Average tall fescue colour and quality ratings (1-9) and clipping yields $\left(\mathrm{g} \mathrm{m}^{-2}\right)$ under different nitrogen rates $\left(\mathrm{NR}, \mathrm{kg}^{-1}\right)$, irrigation levels (IL, \%) and months (M) in the 2007 and 2008 experimental seasons.

\begin{tabular}{|c|c|c|c|c|c|c|}
\hline \multirow[t]{2}{*}{ Factors } & \multicolumn{3}{|c|}{2007} & \multicolumn{3}{|c|}{2008} \\
\hline & Colour & Quality & $\begin{array}{l}\text { Clipping } \\
\text { Yield }\end{array}$ & Colour & Quality & Clipping Yield \\
\hline \multicolumn{7}{|c|}{ NR } \\
\hline $\mathbf{N}_{1}$ & $6.9 b^{1}$ & $6.6 \mathrm{~b}$ & $25.1 \mathrm{~b}$ & $7.1 \mathrm{~b}$ & $6.9 \mathrm{~b}$ & $17.1 \mathrm{~b}$ \\
\hline $\mathbf{N}_{2}$ & $7.6 \mathrm{a}$ & $7.2 \mathrm{a}$ & $35.6 \mathrm{a}$ & $8.0 \mathrm{a}$ & $7.6 \mathrm{a}$ & $33.6 \mathrm{a}$ \\
\hline \multicolumn{7}{|l|}{ IL } \\
\hline $\mathbf{I}_{1}$ & $5.6 \mathrm{~d}$ & $5.0 \mathrm{e}$ & $12.2 \mathrm{e}$ & $6.5 \mathrm{~d}$ & $5.8 \mathrm{~d}$ & $12.8 \mathrm{c}$ \\
\hline $\mathbf{I}_{2}$ & $7.2 \mathrm{c}$ & $6.6 \mathrm{~d}$ & $22.2 \mathrm{~d}$ & $7.3 \mathrm{c}$ & $7.0 \mathrm{c}$ & $19.3 \mathrm{~b}$ \\
\hline $\mathbf{I}_{3}$ & $7.6 \mathrm{bc}$ & $7.1 \mathrm{c}$ & $30.0 \mathrm{c}$ & $7.9 \mathrm{ab}$ & $7.5 \mathrm{~b}$ & $30.6 \mathrm{a}$ \\
\hline $\mathbf{I}_{4}$ & $7.9 \mathrm{ab}$ & $7.7 \mathrm{~b}$ & $41.5 \mathrm{~b}$ & $7.9 \mathrm{ab}$ & $7.8 \mathrm{ab}$ & $32.6 \mathrm{a}$ \\
\hline I5 & $8.3 \mathrm{a}$ & $8.2 \mathrm{a}$ & $45.8 \mathrm{a}$ & $8.1 \mathrm{a}$ & $8.0 \mathrm{a}$ & $31.7 \mathrm{a}$ \\
\hline \multicolumn{7}{|l|}{ M } \\
\hline May & $8.1 \mathrm{a}$ & $7.5 \mathrm{a}$ & $35.4 \mathrm{~b}$ & $8.0 \mathrm{~b}$ & $7.6 \mathrm{~b}$ & $26.2 \mathrm{~b}$ \\
\hline June & $7.3 \mathrm{~b}$ & $7.3 \mathrm{a}$ & $9.8 \mathrm{~d}$ & $7.3 \mathrm{~cd}$ & $6.8 \mathrm{c}$ & $13.3 \mathrm{c}$ \\
\hline July & $7.2 \mathrm{c}$ & $6.8 \mathrm{~b}$ & $40.8 \mathrm{a}$ & $7.3 \mathrm{c}$ & $6.7 \mathrm{c}$ & $15.7 \mathrm{c}$ \\
\hline August & $7.0 \mathrm{c}$ & $6.7 \mathrm{~b}$ & $40.9 \mathrm{a}$ & $7.0 \mathrm{~d}$ & $6.8 \mathrm{c}$ & $29.5 \mathrm{~b}$ \\
\hline September & $6.4 \mathrm{~d}$ & $6.3 c$ & $24.8 \mathrm{c}$ & $8.3 \mathrm{a}$ & $8.2 \mathrm{a}$ & $42.3 \mathrm{a}$ \\
\hline
\end{tabular}

${ }^{1}$ : mean values in the same column followed by the same letter are not significantly different between the treatments at the 0.05 level using the LSD test.

Throughout the experiment, the lowest colour, quality and clipping yield resulted from the lowest irrigation level $\left(I_{1}\right)$ (Table 5). In general, the highest colour, quality and clipping yield were obtained from full $\left(I_{4}\right)$ and excessive $\left(I_{5}\right)$ irrigation treatments. In a similar study conducted using lysimeters in which colour was considered a primary quality criterion, a decrease in the ET rate was associated with a decrease in quality (Feldhake et al., 1984).For tall fescue, a cool season grass, Fry and Butler (1989) also reported that the colour quality decreased when irrigation declined from $100 \%$ to $75 \%$, and $50 \%$ of the potential ET. In our study, an acceptable turfgrass colour and quality were sustained under $I_{2}$ irrigation treatment for the each experimental season. Fry and Butler (1989) demonstrated that field-grown 'Rebel' tall fescue maintained an acceptable quality when irrigated every 2 days at $50 \%$ of the tall fescue's potential ET. In a similar study conducted in Nevada, Dean et al. (1996) reported that tall fescue required $80 \%$ of the potential ET to maintain an acceptable turf quality. Although it should be noted that, variations in drought resistance have been reported among the cultivars of tall fescue, which were attributed mainly to differences in the total root length density and rooting depth (Carrow, 1996; Huang and Gao, 
2000). Additionally, Fu et al. (2004) found that tall fescue irrigated twice weekly maintained an acceptable quality between June and September at deficit irrigation levels of $40 \%$ or $60 \% \mathrm{ET}_{\mathrm{a}}$ (actual evapotranspiration), assuming the turf management could tolerate a period of slight decline in quality.

A gradually decreasing trend in colour and quality was observed from May to September for both of the $\mathrm{N}$ rates in the 2007 (Table 5). The colour and quality ratings and clipping yields obtained in September of 2007 for both of the $\mathrm{N}$ rates were lower than in September of 2008 due to lower amount of rainfall $(3.4 \mathrm{~mm})$ in September 2007 in comparison to that amount of September 2008 (132.2 $\mathrm{mm})$.
The $\mathrm{N}$ rates $\mathrm{x}$ irrigation levels interactions clearly showed that the colour, quality ratings, and clipping yields significantly increased with the $\mathrm{N}$ rate under all of the irrigation treatments for both two years (Table 6). The $I_{4}$ and $I_{5}$ treatments under the $N_{2}$ rate produced significantly higher ratings of colour and quality and clipping yields for tall fescue during both seasons. Feldhake (1981) stated that the quality of nitrogen-deficient turf has showed to decline more rapidly when subjected to moisture stress compared to adequately fertilized. In general, several studies indicated that the turf colour and quality ratings ranged from 1 to 9 , with an acceptable minimum visual quality number of 6 (Kopp and Guillard, 2002; Bilgili and Acikgoz, 2005). In this study, an acceptable turf grass colour and quality were sustained under the $N_{1} I_{2}$ treatment throughout of the each experimental season.

Table 6. Colour and quality ratings (1-9) and clipping yields $\left(\mathrm{g} \mathrm{m}^{-2}\right)$ of tall fescue for the nitrogen rates (NR) $\times$ irrigation levels (IL) interactions in the 2007 and 2008 experimental seasons.

\begin{tabular}{|c|c|c|c|c|c|c|c|}
\hline \multirow{2}{*}{$\begin{array}{l}\text { NR } \\
\left(\operatorname{kg~ha}^{-1}\right)\end{array}$} & \multirow[t]{2}{*}{ IL (\%) } & \multicolumn{3}{|c|}{2007} & \multicolumn{3}{|c|}{2008} \\
\hline & & Colour & Quality & $\begin{array}{l}\text { Clipping } \\
\text { Yield }\end{array}$ & Colour & Quality & $\begin{array}{l}\text { Clipping } \\
\text { Yield }\end{array}$ \\
\hline \multirow[t]{5}{*}{$\mathbf{N}_{1}$} & $\mathbf{I}_{1}$ & $5.2 \mathrm{~g}^{1}$ & $5.0 \mathrm{f}$ & $10.9 \mathrm{~g}$ & $6.3 \mathrm{~d}$ & $5.8 \mathrm{~d}$ & $11.1 \mathrm{f}$ \\
\hline & $\mathbf{I}_{2}$ & $6.7 \mathrm{e}$ & $6.1 \mathrm{e}$ & $17.5 \mathrm{f}$ & $6.9 \mathrm{c}$ & $6.7 \mathrm{c}$ & $14.2 \mathrm{ef}$ \\
\hline & $\mathbf{I}_{3}$ & $7.0 \mathrm{~d}$ & $6.7 \mathrm{~d}$ & $24.8 \mathrm{e}$ & $7.5 \mathrm{~b}$ & $7.3 b c$ & $23.3 \mathrm{c}$ \\
\hline & $\mathbf{I}_{4}$ & $7.6 \mathrm{c}$ & $7.5 \mathrm{c}$ & $31.1 \mathrm{~cd}$ & $7.5 \mathrm{~b}$ & $7.3 b c$ & $20.5 \mathrm{~cd}$ \\
\hline & $\mathbf{I}_{5}$ & $8.1 \mathrm{~b}$ & $7.9 \mathrm{~b}$ & $41.0 \mathrm{~b}$ & $7.6 \mathrm{~b}$ & $7.4 \mathrm{~b}$ & $16.8 \mathrm{de}$ \\
\hline \multirow[t]{5}{*}{$\mathbf{N}_{2}$} & $\mathbf{I}_{1}$ & $5.9 \mathrm{f}$ & $5.1 \mathrm{f}$ & $13.4 \mathrm{fg}$ & $6.8 \mathrm{c}$ & $5.9 \mathrm{~d}$ & $145 \mathrm{~d}-\mathrm{f}$ \\
\hline & $\mathbf{I}_{2}$ & $7.6 \mathrm{c}$ & $7.0 \mathrm{~d}$ & $26.8 \mathrm{de}$ & $7.8 \mathrm{~b}$ & $7.4 \mathrm{~b}$ & $24.4 \mathrm{c}$ \\
\hline & $\mathbf{I}_{3}$ & $8.1 \mathrm{~b}$ & $7.6 \mathrm{c}$ & $35.3 \mathrm{c}$ & $8.4 \mathrm{ab}$ & $7.8 \mathrm{~b}$ & $37.9 \mathrm{~b}$ \\
\hline & $\mathbf{I}_{4}$ & $8.1 \mathrm{~b}$ & $8.0 \mathrm{~b}$ & $51.9 \mathrm{a}$ & $8.4 \mathrm{ab}$ & $8.3 \mathrm{ab}$ & $44.8 \mathrm{a}$ \\
\hline & $\mathbf{I}_{5}$ & $8.4 \mathrm{a}$ & $8.4 \mathrm{a}$ & $50.5 \mathrm{a}$ & $8.6 \mathrm{a}$ & $8.6 \mathrm{a}$ & $46.6 \mathrm{a}$ \\
\hline
\end{tabular}

The $\mathrm{N}$ rates $\mathrm{x}$ months interactions indicated that the colour, quality ratings, and clipping yields significantly increased with the $\mathrm{N}$ rate for both years (Table 7). While the highest turf colour and quality were obtained in the $N_{2}$ treatment and May, clipping yield was obtained in the $\mathrm{N}_{2}$ treatment and May, July and August in 2007. In 2008, highest turf colour was obtained in the $N_{2}$ treatment for both May and September. However, the highest quality and clipping yield were obtained in the $N_{2}$ treatment for only September due to higher amount of rainfall (132.2 $\mathrm{mm})$.

The irrigation levels x months interactions in 2007 and 2008 gave statistically significant colour and quality ratings and clipping yields (Table 8). The interactions showed that the colour and quality ratings decreased from May to September in all irrigation levels for bothyears. In generally, highest turf colour, quality and clipping yield were obtained from $I_{5}$ irrigation level in all months. When irrigation level increased, significant differences in colour and quality ratings and clipping yield soccurred in each month for each year. In particular, the $I_{5}$ irrigation level provided the darkest gren and highest-quality turf throughout the growing seasons. The $I_{1} \mathrm{x}$ September month interaction produced lowest turf colour, quality and clipping yield in two years.
Interactions of $\mathrm{N}$ rates, irrigation levels and months for both study years were statistically significant in terms of the turf colour and quality rating sand clipping yields. In generally, significant increases in the colour and quality ratings and clipping yields occurred, with increasing $\mathrm{N}$ rate under all of the irrigation treatments in each month for both years (Tables 9 and 10). However, those increases varied significantly with irrigation levels. In generally, the irrigation levels under both $\mathrm{N}$ rates in May gave higher colour and quality ratings than other months for both years, with exception of September 2008 due to rainfall $(132.2 \mathrm{~mm})$ and high soil moisture. According to water conservation, acceptable turfgrass colour and quality were sustained under the $N_{1} I_{1}$ treatment in May, $N_{1} I_{2}$ treatment in June (or $N_{2} I_{1}$ treatment in June), July and August and $N_{1} I_{4}$ treatment (or $N_{2} I_{2}$ teratment) in September throughout the 2007 experimental season. Similarly in 2008, acceptable turf grass colour and quality were sustained under the $N_{1} I_{1}$ treatment in May and June, $N_{1} I_{2}$ treatment in July (with the exception of quality rating fells lightly below acceptable level) and August and $N_{1} I_{1}$ treatment in September (due to rainfall of $132.2 \mathrm{~mm}$ and high soil moisture in September 2008) throughout the experimental season. 
Table 7. Colour and quality ratings (1-9) and clipping yields $\left(\mathrm{g} \mathrm{m}^{-2}\right)$ of tall fescue for the nitrogen rates $(\mathrm{NR}) \times$ months $(\mathrm{M})$ interactions in the 2007 and 2008 experimental seasons.

\begin{tabular}{|c|c|c|c|c|c|c|c|}
\hline \multirow{2}{*}{$\begin{array}{l}\text { NR } \\
\left(\mathrm{kg} \mathrm{ha}^{-1}\right)\end{array}$} & \multirow[t]{2}{*}{$\mathbf{M}$} & \multicolumn{3}{|c|}{2007} & \multicolumn{3}{|c|}{2008} \\
\hline & & Colour & Quality & $\begin{array}{l}\text { Clipping } \\
\text { Yield }\end{array}$ & Colour & Quality & $\begin{array}{l}\text { Clipping } \\
\text { Yield }\end{array}$ \\
\hline \multirow[t]{5}{*}{$\mathbf{N}_{1}$} & May & $7.9 \mathrm{ab}^{1}$ & $7.2 \mathrm{bc}$ & $24.8 \mathrm{~cd}$ & $7.6 \mathrm{~b}$ & $7.5 \mathrm{~b}$ & $23.2 \mathrm{~d}$ \\
\hline & June & $7.5 \mathrm{~b}$ & $7.1 \mathrm{~cd}$ & $5.5 \mathrm{f}$ & $7.0 \mathrm{c}$ & $6.5 \mathrm{~d}$ & $9.6 \mathrm{~g}$ \\
\hline & July & $6.7 \mathrm{c}$ & $6.5 \mathrm{f}$ & $37.7 \mathrm{~b}$ & $6.8 \mathrm{c}$ & $6.3 \mathrm{~d}$ & $9.7 \mathrm{~g}$ \\
\hline & August & $6.6 \mathrm{c}$ & $6.6 \mathrm{ef}$ & $36.7 \mathrm{~b}$ & $6.5 \mathrm{c}$ & $6.3 \mathrm{~d}$ & $13.2 \mathrm{fg}$ \\
\hline & September & $6.0 \mathrm{~d}$ & $5.8 \mathrm{~g}$ & $20.6 \mathrm{~d}$ & $7.8 \mathrm{~b}$ & $7.9 \mathrm{~b}$ & $30.0 \mathrm{c}$ \\
\hline \multirow[t]{5}{*}{$\mathbf{N}_{2}$} & May & $8.4 \mathrm{a}$ & $7.8 \mathrm{a}$ & $46.0 \mathrm{a}$ & $8.4 \mathrm{a}$ & $7.8 \mathrm{~b}$ & $29.2 \mathrm{c}$ \\
\hline & June & $8.0 \mathrm{ab}$ & $7.5 \mathrm{ab}$ & $14.0 \mathrm{e}$ & $7.6 \mathrm{~b}$ & $7.1 \mathrm{c}$ & 16.9 ef \\
\hline & July & $7.7 \mathrm{ab}$ & $6.9 \mathrm{de}$ & $43.8 \mathrm{a}$ & $7.8 \mathrm{~b}$ & $7.1 \mathrm{c}$ & $21.7 \mathrm{de}$ \\
\hline & August & $7.4 \mathrm{~b}$ & $6.9 \mathrm{c}-\mathrm{e}$ & $45.1 \mathrm{a}$ & $7.5 \mathrm{~b}$ & $7.3 \mathrm{bc}$ & $45.7 \mathrm{~b}$ \\
\hline & September & $6.7 \mathrm{c}$ & $6.9 \mathrm{de}$ & $29.1 \mathrm{c}$ & $8.8 \mathrm{a}$ & $8.6 \mathrm{a}$ & $54.7 \mathrm{a}$ \\
\hline
\end{tabular}
test.

Table 8. Colour and quality ratings (1-9) and clipping yields $\left(\mathrm{g} \mathrm{m}^{-2}\right)$ of tall fescue for the irrigation levels (IL) $\times$ months (M) interactions in the 2007 and 2008 experimental seasons.

\begin{tabular}{|c|c|c|c|c|c|c|c|}
\hline \multirow[t]{2}{*}{ IL (\%) } & \multirow[t]{2}{*}{$\mathbf{M}$} & \multicolumn{3}{|c|}{2007} & \multicolumn{3}{|c|}{2008} \\
\hline & & Colour & Quality & $\begin{array}{l}\text { Clipping } \\
\text { Yield }\end{array}$ & Colour & Quality & $\begin{array}{l}\text { Clipping } \\
\text { Yield }\end{array}$ \\
\hline \multirow[t]{5}{*}{$\mathbf{I}_{1}$} & May & $8.3 \mathrm{a}-\mathrm{c}^{1}$ & $6.6 \mathrm{gh}$ & $27.0 \mathrm{fg}$ & $8.3 \mathrm{a}-\mathrm{c}$ & $6.6 \mathrm{gh}$ & $21.7 \mathrm{fg}$ \\
\hline & June & $6.5 \mathrm{gh}$ & $6.0 \mathrm{ij}$ & $2.0 \mathrm{mn}$ & $6.5 \mathrm{gh}$ & $6.0 \mathrm{ij}$ & $9.7 \mathrm{hi}$ \\
\hline & July & $5.3 \mathrm{i}$ & $4.6 \mathrm{k}$ & $14.0 \mathrm{i}-\mathrm{k}$ & $5.3 \mathrm{i}$ & $4.6 \mathrm{k}$ & $4.2 \mathrm{i}$ \\
\hline & August & $4.9 \mathrm{i}$ & $4.3 \mathrm{k}$ & $17.8 \mathrm{~h}-\mathrm{j}$ & $4.9 \mathrm{i}$ & $4.3 \mathrm{k}$ & $3.5 \mathrm{i}$ \\
\hline & September & $2.9 \mathrm{j}$ & 3.51 & $0.0 \mathrm{n}$ & $2.9 \mathrm{j}$ & 3.51 & 25.0 ef \\
\hline \multirow[t]{5}{*}{$\mathbf{I}_{2}$} & May & $8.5 \mathrm{a}$ & $7.3 \mathrm{c}-\mathrm{f}$ & 30.4 ef & $8.5 \mathrm{a}$ & $7.3 \mathrm{c}-\mathrm{f}$ & $24.3 \mathrm{ef}$ \\
\hline & June & $7.4 \mathrm{ef}$ & $6.8 \mathrm{f}-\mathrm{h}$ & $5.81-n$ & $7.4 \mathrm{ef}$ & $6.8 \mathrm{f}-\mathrm{h}$ & $13.1 \mathrm{~h}$ \\
\hline & July & $7.0 \mathrm{fg}$ & $6.5 \mathrm{hi}$ & $36.7 \mathrm{de}$ & $7.0 \mathrm{fg}$ & $6.5 \mathrm{hi}$ & $7.9 \mathrm{hi}$ \\
\hline & August & $6.6 \mathrm{gh}$ & $6.5 \mathrm{hi}$ & $34.5 \mathrm{ef}$ & $6.6 \mathrm{gh}$ & $6.5 \mathrm{hi}$ & $14.3 \mathrm{gh}$ \\
\hline & September & $6.3 \mathrm{~h}$ & $5.8 \mathrm{j}$ & $3.61-n$ & $6.3 \mathrm{~h}$ & $5.8 \mathrm{j}$ & $36.7 \mathrm{~cd}$ \\
\hline \multirow[t]{5}{*}{$\mathbf{I}_{3}$} & May & $8.3 \mathrm{ab}$ & 7. bc & 31.9 ef & $8.3 \mathrm{ab}$ & $7.6 \mathrm{bc}$ & 25.7 ef \\
\hline & June & $8.1 \mathrm{a}-\mathrm{d}$ & $7.4 \mathrm{c}-\mathrm{e}$ & $8.0 \mathrm{k}-\mathrm{m}$ & $8.1 \mathrm{a}-\mathrm{d}$ & $7.4 \mathrm{c}-\mathrm{e}$ & $13.9 \mathrm{gh}$ \\
\hline & July & $7.6 \mathrm{c}-\mathrm{f}$ & $7.1 \mathrm{e}-\mathrm{g}$ & $46.5 \mathrm{bc}$ & $7.6 \mathrm{c}-\mathrm{f}$ & $7.1 \mathrm{e}-\mathrm{g}$ & $15.3 \mathrm{gh}$ \\
\hline & August & $7.5 \mathrm{ef}$ & $7.2 \mathrm{~d}-\mathrm{f}$ & $43.4 \mathrm{~cd}$ & $7.5 \mathrm{ef}$ & $7.2 \mathrm{~d}-\mathrm{f}$ & $41.9 \mathrm{c}$ \\
\hline & September & $6.4 \mathrm{gh}$ & $3.5 \mathrm{hi}$ & $20.5 \mathrm{ghi}$ & $6.4 \mathrm{gh}$ & $6.4 \mathrm{hi}$ & $56.3 \mathrm{a}$ \\
\hline \multirow[t]{5}{*}{$\mathbf{I}_{4}$} & May & $7.5 \mathrm{~d}-\mathrm{f}$ & $8.0 \mathrm{ab}$ & $44.0 \mathrm{~cd}$ & $7.5 \mathrm{~d}-\mathrm{f}$ & $8.0 \mathrm{ab}$ & $28.3 \mathrm{ef}$ \\
\hline & June & $8.4 \mathrm{a}$ & $8.0 \mathrm{ab}$ & $10.5 \mathrm{j}-1$ & $8.4 \mathrm{a}$ & $8.0 \mathrm{ab}$ & $14.5 \mathrm{gh}$ \\
\hline & July & 7.9 a-e & $7.2 \mathrm{c}-\mathrm{g}$ & $53.7 \mathrm{ab}$ & $7.9 \mathrm{ab}-\mathrm{e}$ & $7.2 \mathrm{c}-\mathrm{g}$ & $24.9 \mathrm{ef}$ \\
\hline & August & 7.9 b-f & 7.9 a-e & $54.6 \mathrm{a}-\mathrm{c}$ & 7.9 a-f & 7.9 a-e & $45.4 \mathrm{a}-\mathrm{c}$ \\
\hline & September & $7.8 \mathrm{~b}-\mathrm{e}$ & 7.6 b-d & $44.8 \mathrm{c}$ & $7.8 \mathrm{~b}-\mathrm{e}$ & $7.6 \mathrm{~b}-\mathrm{d}$ & $50.0 \mathrm{ab}$ \\
\hline \multirow[t]{5}{*}{$\mathbf{I}_{5}$} & May & 8.0 a-e & $8.1 \mathrm{ab}$ & $43.8 \mathrm{~cd}$ & 8.0 a-e & $8.0 \mathrm{ab}$ & $31.1 \mathrm{de}$ \\
\hline & June & $8.3 \mathrm{a}-\mathrm{c}$ & $8.3 \mathrm{a}$ & $22.5 \mathrm{gh}$ & $8.3 \mathrm{a}-\mathrm{c}$ & $8.3 \mathrm{a}$ & $15.2 \mathrm{gh}$ \\
\hline & July & $8.3 \mathrm{a}-\mathrm{c}$ & $8.1 \mathrm{ab}$ & $53.0 \mathrm{ab}$ & $8.3 \mathrm{a}-\mathrm{c}$ & $8.0 \mathrm{ab}$ & $26.1 \mathrm{ef}$ \\
\hline & August & $8.3 \mathrm{a}-\mathrm{c}$ & $8.1 \mathrm{ab}$ & $54.3 \mathrm{a}$ & $8.3 \mathrm{a}-\mathrm{c}$ & $8.1 \mathrm{ab}$ & $42.3 \mathrm{bc}$ \\
\hline & September & $8.5 \mathrm{a}$ & $8.4 \mathrm{a}$ & $55.3 \mathrm{a}$ & $8.5 \mathrm{a}$ & $8.4 \mathrm{a}$ & $43.6 \mathrm{bc}$ \\
\hline
\end{tabular}


Table 9. Colour and quality ratings (1-9) and clipping yields $\left(\mathrm{g} \mathrm{m}^{-2}\right)$ of tall fescue for the the nitrogen rates $(\mathrm{NR}) \times$ irrigation levels (IL) $\times$ months (M) interactions in the 2007 .

\begin{tabular}{|c|c|c|c|c|c|c|}
\hline NR $\left(\mathrm{kg} \mathrm{ha}^{-1}\right)$ & IL (\%) & May & June & July & August & September \\
\hline \multicolumn{7}{|l|}{ Colour } \\
\hline \multirow[t]{5}{*}{$\mathbf{N}_{1}$} & $\mathbf{I}_{1}$ & $8.0 \mathrm{ab}^{1}$ & $6.3 \mathrm{~cd}$ & $4.5 \mathrm{e}$ & $4.5 \mathrm{e}$ & $2.8 \mathrm{f}$ \\
\hline & $\mathbf{I}_{2}$ & $8.0 \mathrm{ab}$ & $7.3 \mathrm{bc}$ & $6.3 \mathrm{~cd}$ & $6.0 \mathrm{~cd}$ & $6.0 \mathrm{~cd}$ \\
\hline & $\mathbf{I}_{3}$ & $7.8 \mathrm{~b}$ & $7.8 \mathrm{~b}$ & $7.0 \mathrm{~cd}$ & $6.5 \mathrm{c}$ & $5.5 \mathrm{~d}$ \\
\hline & $\mathbf{I}_{4}$ & $7.5 \mathrm{~b}$ & $8.0 \mathrm{ab}$ & $7.5 \mathrm{~b}$ & $7.5 \mathrm{~b}$ & $7.5 \mathrm{~b}$ \\
\hline & $\mathbf{I}_{5}$ & $8.0 \mathrm{ab}$ & $8.3 \mathrm{ab}$ & $8.0 \mathrm{ab}$ & $8.0 \mathrm{ab}$ & $8.3 \mathrm{ab}$ \\
\hline \multirow[t]{5}{*}{$\mathbf{N}_{2}$} & $\mathbf{I}_{1}$ & $8.5 \mathrm{a}$ & $6.8 \mathrm{c}$ & $6.0 \mathrm{~cd}$ & $5.3 \mathrm{de}$ & $3.0 \mathrm{f}$ \\
\hline & $\mathbf{I}_{2}$ & $9.0 \mathrm{a}$ & $7.5 \mathrm{~b}$ & $7.8 \mathrm{~b}$ & $7.3 \mathrm{bc}$ & $6.5 \mathrm{c}$ \\
\hline & $\mathbf{I}_{3}$ & $8.8 \mathrm{a}$ & $8.5 \mathrm{a}$ & $8.0 \mathrm{ab}$ & $8.0 \mathrm{ab}$ & $7.3 \mathrm{bc}$ \\
\hline & $\mathbf{I}_{4}$ & $7.5 \mathrm{~b}$ & $8.8 \mathrm{a}$ & $8.3 \mathrm{ab}$ & $8.3 \mathrm{ab}$ & $8.0 \mathrm{ab}$ \\
\hline & $\mathbf{I}_{5}$ & $8.0 \mathrm{ab}$ & $8.3 \mathrm{ab}$ & $8.5 \mathrm{a}$ & $8.5 \mathrm{a}$ & $8.8 \mathrm{a}$ \\
\hline \multicolumn{7}{|l|}{ Quality } \\
\hline \multirow[t]{5}{*}{$\mathbf{N}_{1}$} & $\mathbf{I}_{1}$ & $6.5 \mathrm{k}-\mathrm{m}$ & $5.5 n-p$ & $4.5 \mathrm{qr}$ & $4.8 \mathrm{q}$ & $3.5 \mathrm{~s}$ \\
\hline & $\mathbf{I}_{2}$ & $7.0 \mathrm{f}-\mathrm{k}$ & $6.5 \mathrm{k}-\mathrm{m}$ & $6.31-n$ & $6.0 \mathrm{~m}-\mathrm{o}$ & $4.8 \mathrm{pq}$ \\
\hline & $\mathbf{I}_{3}$ & $7.3 \mathrm{e}-\mathrm{k}$ & $7.3 \mathrm{e}-\mathrm{k}$ & $7.0 \mathrm{~g}-1$ & $6.7 \mathrm{j}-1$ & $5.3 \mathrm{o}-\mathrm{q}$ \\
\hline & $\mathbf{I}_{4}$ & $7.5 \mathrm{~d}-\mathrm{i}$ & $7.8 b-f$ & $7.0 \mathrm{f}-1$ & $7.9 \mathrm{a}-\mathrm{j}$ & $7.5 \mathrm{~d}-\mathrm{i}$ \\
\hline & $\mathbf{I}_{5}$ & $7.8 \mathrm{~b}-\mathrm{f}$ & $8.3 \mathrm{a}-\mathrm{d}$ & $7.8 \mathrm{~b}-\mathrm{f}$ & $7.8 \mathrm{~b}-\mathrm{f}$ & $8.0 \mathrm{a}-\mathrm{e}$ \\
\hline \multirow[t]{5}{*}{$\mathbf{N}_{2}$} & $\mathbf{I}_{1}$ & $6.8 \mathrm{~h}-\mathrm{m}$ & $6.5 \mathrm{k}-\mathrm{m}$ & $4.8 \mathrm{pq}$ & $3.8 \mathrm{rs}$ & $3.5 \mathrm{~s}$ \\
\hline & $\mathbf{I}_{2}$ & $7.5 \mathrm{~d}-\mathrm{h}$ & $7.0 \mathrm{f}-1$ & $6.8 \mathrm{i}-\mathrm{m}$ & $7.0 \mathrm{f}-1$ & $6.8 \mathrm{i}-\mathrm{m}$ \\
\hline & $\mathbf{I}_{3}$ & $8.0 \mathrm{a}-\mathrm{e}$ & $7.5 \mathrm{~d}-\mathrm{i}$ & $7.2 \mathrm{f}-\mathrm{k}$ & $7.6 \mathrm{~d}-\mathrm{g}$ & $7.5 \mathrm{~d}-\mathrm{i}$ \\
\hline & $\mathbf{I}_{4}$ & $8.5 \mathrm{ab}$ & $8.3 \mathrm{a}-\mathrm{d}$ & $7.4 e-j$ & $7.9 \mathrm{a}-\mathrm{j}$ & $7.8 \mathrm{c}-\mathrm{f}$ \\
\hline & $\mathbf{I}_{5}$ & $8.3 \mathrm{a}-\mathrm{d}$ & $8.3 \mathrm{a}-\mathrm{d}$ & $8.3 \mathrm{a}-\mathrm{d}$ & $8.5 \mathrm{a}-\mathrm{c}$ & $8.8 \mathrm{a}$ \\
\hline \multicolumn{7}{|c|}{ Clipping Yield } \\
\hline \multirow[t]{5}{*}{$\mathbf{N}_{1}$} & $\mathbf{I}_{1}$ & $16.3 \mathrm{r}-\mathrm{w}$ & $2.0[\backslash$ & 14.4 s-y & $21.9 \mathrm{p}-\mathrm{t}$ & $0.0 \backslash$ \\
\hline & $\mathbf{I}_{2}$ & $19.9 q-u$ & $4.0 \mathrm{y}-1$ & $31.21-\mathrm{p}$ & $29.3 \mathrm{~m}-\mathrm{q}$ & $3.4 \mathrm{z}-1$ \\
\hline & $\mathbf{I}_{3}$ & 26.4 n-r & $5.0 \times-1$ & $41.0 \mathrm{~h}-1$ & $33.9 \mathrm{k}-\mathrm{n}$ & $17.7 \mathrm{r}-\mathrm{v}$ \\
\hline & $\mathbf{I}_{4}$ & $30.81-q$ & $6.0 \mathrm{w}-1$ & 46.9 e-j & $38.5 \mathrm{f}-\mathrm{p}$ & $33.3 \mathrm{k}-\mathrm{o}$ \\
\hline & $\mathbf{I}_{5}$ & $30.71-q$ & $10.5 \mathrm{u}-\backslash$ & $55.1 \mathrm{a}-\mathrm{f}$ & $60.1 \mathrm{a}-\mathrm{c}$ & $48.6 \mathrm{~d}-\mathrm{i}$ \\
\hline \multirow[t]{5}{*}{$\mathbf{N}_{2}$} & $\mathbf{I}_{1}$ & $37.8 \mathrm{i}-\mathrm{m}$ & $2.0[1$ & $13.6 \mathrm{~s}-\mathrm{z}$ & $13.6 \mathrm{~s}-\mathrm{z}$ & $0.0 \backslash$ \\
\hline & $\mathbf{I}_{2}$ & 40.9 h-1 & $7.5 \mathrm{v}-1$ & $42.2 \mathrm{~g}-\mathrm{k}$ & 39.7 i-m & $3.8 y-1$ \\
\hline & $\mathbf{I} 3$ & $37.4 \mathrm{j}-\mathrm{n}$ & $11.0 \mathrm{t}-[$ & $51.9 \mathrm{~b}-\mathrm{g}$ & $52.9 \mathrm{~b}-\mathrm{f}$ & $23.3 \mathrm{o}-\mathrm{s}$ \\
\hline & $\mathbf{I}_{4}$ & 57.3 a-e & $15.0 \mathrm{~s}-\mathrm{X}$ & $60.5 \mathrm{a}-\mathrm{d}$ & $70.7 \mathrm{a}$ & $56.2 \mathrm{a}-\mathrm{e}$ \\
\hline & $\mathbf{I}_{5}$ & 56.9 a-e & $34.5 \mathrm{k}-\mathrm{n}$ & $50.9 \mathrm{c}-\mathrm{h}$ & $48.4 \mathrm{e}-\mathrm{i}$ & $62.0 \mathrm{ab}$ \\
\hline
\end{tabular}


Table 10. Colour and quality ratings (1-9) and clipping yields $\left(\mathrm{g} \mathrm{m}^{-2}\right)$ of tall fescue for the the nitrogen rates $(\mathrm{NR}) \times$ irrigation levels (IL) $\times$ months (M) interactions in the 2008 .

\begin{tabular}{|c|c|c|c|c|c|c|}
\hline NR $\left(\operatorname{kg~ha}^{-1}\right)$ & IL (\%) & May & June & July & August & September \\
\hline \multicolumn{7}{|c|}{ Colour } \\
\hline \multirow[t]{5}{*}{$\mathbf{N}_{1}$} & $\mathbf{I}_{1}$ & $7.0 \mathrm{j}-\mathrm{o}^{1}$ & $6.81-q$ & $6.3 p-q$ & $4.3 \mathrm{r}$ & $7.0 \mathrm{j}-\mathrm{o}$ \\
\hline & $\mathbf{I}_{2}$ & $7.5 \mathrm{f}-\mathrm{m}$ & $7.0 \mathrm{j}-\mathrm{p}$ & $6.3 \mathrm{o}-\mathrm{q}$ & $6.3 \mathrm{o}-\mathrm{q}$ & $7.5 \mathrm{f}-\mathrm{m}$ \\
\hline & $\mathbf{I}_{3}$ & $7.5 \mathrm{f}-\mathrm{m}$ & $6.81-q$ & $7.2 \mathrm{j}-\mathrm{n}$ & $8.1 \mathrm{~b}-\mathrm{h}$ & $7.8 \mathrm{~d}-\mathrm{k}$ \\
\hline & $\mathbf{I}_{4}$ & $7.8 \mathrm{~d}-\mathrm{j}$ & $7.0 \mathrm{k}-\mathrm{p}$ & $7.4 \mathrm{~g}-\mathrm{n}$ & $6.9 \mathrm{~h}-\mathrm{q}$ & 8.3 a-f \\
\hline & $\mathbf{I}_{5}$ & $8.3 \mathrm{a}-\mathrm{g}$ & $7.3 \mathrm{i}-\mathrm{n}$ & $7.0 \mathrm{j}-\mathrm{p}$ & $7.0 \mathrm{j}-\mathrm{p}$ & $8.3 \mathrm{a}-\mathrm{g}$ \\
\hline \multirow[t]{5}{*}{$\mathbf{N}_{2}$} & $\mathbf{I}_{1}$ & $7.8 \mathrm{e}-\mathrm{k}$ & $7.3 \mathrm{i}-\mathrm{n}$ & $6.0 \mathrm{q}$ & $4.5 \mathrm{r}$ & $8.5 \mathrm{a}-\mathrm{d}$ \\
\hline & $\mathbf{I}_{2}$ & $8.8 \mathrm{a}-\mathrm{c}$ & $7.0 \mathrm{j}-\mathrm{p}$ & $7.5 \mathrm{f}-\mathrm{m}$ & $6.5 \mathrm{n}-\mathrm{q}$ & $9.0 \mathrm{a}$ \\
\hline & $\mathbf{I}_{3}$ & $8.8 \mathrm{ab}$ & $7.5 \mathrm{f}-\mathrm{m}$ & $8.0 \mathrm{c}-\mathrm{i}$ & $8.7 \mathrm{ab}$ & $9.0 \mathrm{a}$ \\
\hline & $\mathbf{I}_{4}$ & $8.5 \mathrm{a}-\mathrm{e}$ & $8.0 \mathrm{~b}-\mathrm{i}$ & 8.4 a-e & 8.8 a-f & 8.5 a-e \\
\hline & $\mathbf{I}_{5}$ & $8.0 \mathrm{~b}-\mathrm{i}$ & $8.0 \mathrm{~b}-\mathrm{i}$ & $9.0 \mathrm{a}$ & $9.0 \mathrm{a}$ & $9.0 \mathrm{a}$ \\
\hline \multicolumn{7}{|c|}{ Quality } \\
\hline \multirow[t]{5}{*}{$\mathbf{N}_{1}$} & $\mathbf{I}_{1}$ & $7.0 \mathrm{bc}$ & $6.3 \mathrm{~cd}$ & $5.0 \mathrm{e}$ & $3.3 \mathrm{f}$ & $7.5 \mathrm{~b}$ \\
\hline & $\mathbf{I}_{2}$ & $7.3 \mathrm{bc}$ & $6.0 \mathrm{~cd}$ & $5.8 \mathrm{~d}$ & $6.5 \mathrm{c}$ & $7.8 \mathrm{~b}$ \\
\hline & $\mathbf{I}_{3}$ & $7.3 \mathrm{bc}$ & $6.3 \mathrm{~cd}$ & $6.8 \mathrm{c}$ & $8.0 \mathrm{ab}$ & $8.0 \mathrm{ab}$ \\
\hline & $\mathbf{I}_{4}$ & $7.8 \mathrm{~b}$ & $7.0 \mathrm{bc}$ & $7.0 \mathrm{bc}$ & $7.8 \mathrm{~b}$ & $8.0 \mathrm{ab}$ \\
\hline & $\mathbf{I}_{5}$ & $8.0 \mathrm{ab}$ & $7.0 \mathrm{bc}$ & $7.0 \mathrm{bc}$ & $7.0 \mathrm{bc}$ & $8.0 \mathrm{ab}$ \\
\hline \multirow[t]{5}{*}{$\mathbf{N}_{2}$} & $\mathbf{I}_{1}$ & $7.3 \mathrm{bc}$ & $5.8 \mathrm{~d}$ & $5.0 \mathrm{e}$ & $3.5 \mathrm{f}$ & $7.8 \mathrm{~b}$ \\
\hline & $\mathbf{I}_{2}$ & $7.8 \mathrm{~b}$ & $6.8 \mathrm{c}$ & $6.8 \mathrm{c}$ & $6.8 \mathrm{c}$ & $8.8 \mathrm{a}$ \\
\hline & $\mathbf{I}_{3}$ & $7.5 \mathrm{~b}$ & $7.0 \mathrm{bc}$ & $7.0 \mathrm{bc}$ & $7.8 \mathrm{~b}$ & $9.0 \mathrm{a}$ \\
\hline & $\mathbf{I}_{4}$ & $8.0 \mathrm{ab}$ & $7.8 \mathrm{~b}$ & $8.0 \mathrm{ab}$ & $9.0 \mathrm{a}$ & $8.5 \mathrm{a}$ \\
\hline & $\mathbf{I}_{5}$ & $8.5 \mathrm{a}$ & $8.0 \mathrm{ab}$ & $8.8 \mathrm{a}$ & $8.8 \mathrm{a}$ & $9.0 \mathrm{a}$ \\
\hline \multicolumn{7}{|c|}{ Clipping Yield } \\
\hline \multirow[t]{5}{*}{$\mathbf{N}_{1}$} & $\mathbf{I}_{1}$ & $19.2 \mathrm{j}-\mathrm{s}$ & $5.7 \mathrm{u}-\mathrm{v}$ & $3.7 \mathrm{u}-\mathrm{v}$ & $1.3 \mathrm{v}$ & $25.6 \mathrm{~g}-1$ \\
\hline & $\mathbf{I}_{2}$ & $22.1 \mathrm{j}-\mathrm{p}$ & $10.8 \mathrm{p}-\mathrm{v}$ & $6.4 \mathrm{t}-\mathrm{v}$ & $8.2 \mathrm{~s}-\mathrm{v}$ & $23.4 \mathrm{i}-\mathrm{n}$ \\
\hline & $\mathbf{I}_{3}$ & $22.8 \mathrm{i}-\mathrm{O}$ & $10.2 \mathrm{q}-\mathrm{v}$ & $11.9 \mathrm{o}-\mathrm{V}$ & $27.8 \mathrm{~g}-\mathrm{k}$ & $43.7 \mathrm{de}$ \\
\hline & $\mathbf{I}_{4}$ & $26.4 \mathrm{~g}-1$ & $9.3 \mathrm{r}-\mathrm{v}$ & $14.91-\mathrm{u}$ & $16.2 \mathrm{i}-\mathrm{V}$ & 35.9 e-h \\
\hline & $\mathbf{I}_{5}$ & $25.7 \mathrm{~g}-1$ & $11.9 \mathrm{n}-\mathrm{v}$ & $11.8 \mathrm{n}-\mathrm{v}$ & $12.9 \mathrm{~m}-\mathrm{v}$ & $21.5 \mathrm{j}-\mathrm{q}$ \\
\hline \multirow[t]{5}{*}{$\mathbf{N}_{2}$} & $\mathbf{I}_{1}$ & $24.2 \mathrm{~h}-\mathrm{m}$ & $13.6 \mathrm{~m}-\mathrm{u}$ & $4.8 \mathrm{uv}$ & $5.6 \mathrm{uv}$ & $24.5 \mathrm{~h}-\mathrm{m}$ \\
\hline & $\mathbf{I}_{2}$ & $26.6 \mathrm{~g}-1$ & $15.31-u$ & $9.5 \mathrm{r}-\mathrm{v}$ & $20.4 \mathrm{j}-\mathrm{r}$ & $50.0 \mathrm{~cd}$ \\
\hline & $\mathbf{I}_{3}$ & $28.6 \mathrm{~g}-\mathrm{k}$ & $17.6 \mathrm{k}-\mathrm{t}$ & $18.7 \mathrm{k}-\mathrm{s}$ & $55.9 \mathrm{bc}$ & $68.9 \mathrm{a}$ \\
\hline & $\mathbf{I}_{4}$ & $30.3 \mathrm{f}-\mathrm{j}$ & $19.7 \mathrm{j}-\mathrm{s}$ & 35.0 e-i & $74.7 \mathrm{a}$ & $64.4 \mathrm{ab}$ \\
\hline & $\mathbf{I}_{5}$ & $36.5 \mathrm{e}-\mathrm{g}$ & $18.6 \mathrm{k}-\mathrm{s}$ & $40.4 \mathrm{~d}-\mathrm{f}$ & $71.7 \mathrm{a}$ & $65.7 \mathrm{ab}$ \\
\hline
\end{tabular}

${ }^{1}$ : mean values in the same column followed by the same letter are not significantly different between the treatments at the 0.05 level using the LSD test.

\section{CONCLUSIONS}

A 2-year study was conducted to investigate the visual turfgrass colour and quality and clipping yield responses of tall fescue to different irrigation levels and nitrogen rates under sub-humid climatic conditions. The treatments consisted of five levels of irrigation, $25 \%\left(I_{1}\right), 50 \%\left(I_{2}\right)$, $75 \%\left(I_{3}\right), 100 \%\left(I_{4}\right)$ and $125 \%\left(I_{5}\right)$, of the evaporation measured from a Class A pan and two rates of nitrogen, $25 \mathrm{~kg} \mathrm{~N}^{-1}\left(N_{1}\right)$ and $50 \mathrm{~kg} \mathrm{~N}^{-1}\left(N_{2}\right)$. The $\mathrm{N}$ rates were applied as a monthly rate during May-September for both years. The irrigation was applied at 3-day intervals during May-September for both years. The following conclusions could be extracted from presented results.

1. The results of this study showed that the $I_{4}$ and $I_{5}$ treatments under the $N_{2}$ rate produced significantly higher ratings of colour, quality and, clipping yields during the both years.

2. The $N_{2} I_{4}$ treatment resulted in a sufficiently dark turf colour and quality; to achieve better seasonal turf quality under sub-humid conditions, this schedule can be adapted by evaluating the level of irrigation and $\mathrm{N}$ rate.

3. Based on the results of this study, it is concluded that an acceptable turf quality can be sustained under the $N_{1} I_{1}$ treatment in May, $N_{1} I_{2}$ treatment in June, July and August and $N_{1} I_{4}$ treatment in September (or $N_{2} I_{2}$ treatment in September) according to water conservation. When rainfall amount is high $(132.2 \mathrm{~mm})$ in September, the $N_{1} I_{1}$ treatment may sustain acceptable turf quality for this month. 


\section{ACKNOWLEDGEMENTS}

This research was funded through the grant from The Scientific and Technical Research Council of Turkey (TUBITAK-1050584; Project Leader: Prof. Dr. Esvet AÇIKGÖZ). The authors are indebted to Project Management Centre of Uludağ University in Bursa, Turkey for editing the English of this manuscript. Many thanks to Prof. Dr. Dale A. DEVITT from School of Life Science, University of Nevada, Las Vegas, USA and Assoc. Prof. Dr. Hakan BÜYÜKCANGAZ from Biosystems Engineering Department, Faculty of Agriculture, University of Uludağ, Bursa-Turkey for their valuable edits and comments.

\section{LITERATURE CITED}

Barton, L., G.G.Y. Wan, R.P. Buck and T.D. Colmer. 2009. Nitrogen increases evapotranspiration and growth of a warm-season turfgrass. Agron. J. 101(1): 17-24.

Bastug, R. and D. Buyuktas. 2003. The effects of different irrigation levels applied in golf courses on some quality characteristics of turfgrass. Irrig. Sci.22(2): 87-93.

Beard, J.B. 1973. Turfgrass: Science and Culture. Englewood Cliffs, USA.

Bilgili, U. and E. Acikgoz. 2005. Year-round nitrogen fertilization effects on growth and quality of sports turf mixtures. J. Plant Nutr. 28(2): 299-307.

Bilgili, U. and E. Acikgoz. 2011. Effects of slow-release fertilizers on turf quality in a turf mixture. Turk. J. Field Crops 16(2): 130-136.

Bilgili, U., F.O. Topac-Sagban, I. Surer, N. Caliskan, P. Uzun and E. Acikgoz. 2011. Effects of waste water sludge top dressing on color, quality, and clipping yield of a turfgrass mixture. HortScience 46(9): 1308-1313.

Brown, C.A., D.A. Devitt and R.L. Morris. 2004.Water use and physiological response of tall fescue turf water deficit irrigation in an arid environment. HortScience39(2): 388393.

Candogan, B.N. and S. Yazgan. 2010. The effects of different irrigation levels on vegetative growth of young dwarf cherry trees in a sub-humid climate. Pak. J. Bot. 42(5): 3399-3408.

Candogan, B.N, M. Sincik, H. Buyukcangaz, C. Demirtas, A.T. Goksoy and S. Yazgan. 2013. Yield, quality and crop water stress index relationships for deficit-irrigated soybean [Glycine max (L.) Merr.] in sub-humid climatic conditions. Agric. Water Manage. 118(15): 113-121.

Cardenas-Lailhacar, B., M.D. Dukes and G.L. Miller. 2008. Sensor-based automation of irrigation on Bermuda grass during wet weather conditions. J. Irrig. Drain. Eng. 134(2): $120-128$.

Carrow, R.N. 1996.Drought avoidance characteristics of diverse tall fescue cultivars. Crop Sci.36(2): 371-377.

Carrow, R.N. and R.R. Duncan, 2003. Improving droughtresistance and persistence in turf-type tall fescue. Crop Sci.43(3): 978-984.

Cereti, C.F., F. Rossini and R. Ruggeri. 2009. Reduction of irrigation on tall fescue and Bermuda grass turfs in a Mediterranean environment. Int. Turfgrass Soc. Res. J. 11:918.

Danielson, R.E., C.M. Feldhake and W.E. Hart. 1981. Urban lawn irrigation and management practices for water saving with minimum effect on lawn quality. Completion Report to OWRT, Project No. A-043-COLO.Colorado Water Resources Research Institute, Colorado State University. Fort Collins, USA, 129 p.
Dean, D.E., D.A. Devitt, L.S. Verchick and R.L. Morris. 1996. Turfgrass quality, growth, and water use as influenced by salinity and water stress. Agron. J.88(5): 844-849.

Devitt, D.A., R.L. Morris and D.C. Bowman. 1992. Evapotranspiration, crop coefficients, and leaching fractions of irrigated desert turfgrass systems. Agron. J. 84(4):717723.

Doty, J.A., W.S. Braunworth, S.Tan Jr., P.B. Lombard and R.D. William. 1990. Evapotranspiration of cool-season grasses grown with minimal maintenance. HortScience25(5): 529531.

Ebdon, J.S., A.M. Petrovic and R.A. White. 1999 Interaction of nitrogen, phosphorus, and potassium on evapotranspiration rate and growth of Kentucky bluegrass. Crop Sci.39(1): 209218.

Emekli, Y., R. Bastug, D. Buyuktas andN.Y. Emekli. 2007.Evaluation of a crop water stress index for irrigation scheduling of bermudagrass.Agric. Water Manage.90(3): 205-212.

Ervin, E.H. and A.J. Koski. 1998. Drought avoidance aspects and crop coefficients of Kentucky bluegrass and tall fescue turfs in the semiarid west. Crop Sci.38(3): 788-795.

Feldhake, C.M. 1981. Turfgrass evapotranspiration and micro environment interaction: $\mathrm{PhD}$. dissertation. Colorado State University, Fort Collins, USA, 147 p.

Feldhake, C.M., R.E. Danielson and J.D. Butler. 1983.Turfgrass evapotranspiration. I. Factors influencing rate in urban environments. Agron. J.75(5): 824-830.

Feldhake, C.M., R.E. Danielson and J.D. Butler. 1984. Turfgrass evapotranspiration. II. Responses to deficit irrigation. Agron. J. 76(1): 85-89.

Fry,J.D. and J.D. Butler. 1989. Responses of tall and hard fescue to deficit irrigation.Crop Sci. 29(6): 1536-1541.

Fu, J., J. Fry and B. Huang. 2004. Minimum water requirements of four turfgrasses in the transition zone. Hort Science 39(7): $1740-1744$.

Gibeault, V.A., J.L. Meyer, V.B. Younger and S.T. Cockerham. 1985. Irrigation of turfgrass below replacement of evapotranspiration as a means of water conservations: performance of commonly used turfgrasses: $5^{\text {th }}$ International Turfgrass Research Conference, 347-356, Avignon, France.

Huang, B., J.D. Fry and B. Wang. 1998. Water relations and canopy characteristic of tall fescue cultivars during and after drought stress. Hort Science 33(5): 837-840.

Huang, B. And H. Gao.2000. Root physiological characteristics associated with drought resistance in tall fescue cultivars. Crop Sci. 40(1): 196-203.

Jensen, M.E. 1980. Design and Operation of Farm Irrigation Systems. An ASAE monograph, number 3 in a series published by American Society of Agricultural Engineers (ASAE). Niles Road, USA.

Jensen, M.E., R.D.Burman and R.G. Allen. 1990. Evapotranspiration and Irrigation Water Requirements. Manuals and Reports on Engineering Practices, No. 70, ASCE. New York, USA.

Karcher, D.E. andM.D. Richardson. 2003. Quantifying turfgrass colour using digital image analysis. Crop Sci. 43(3): 943951.

Karcher, D.E. and M.D. Richardson. 2005. Batch analysis of digital images to evaluate turfgrass characteristics. Crop Sci. 45(4): 1536-1539.

Kneebone, W.R., D.M. Kopec and C.F. Mancino. 1992. Water Requirement and Irrigation. In: Turfgrass, 441-472, Agronomy Monograph 32, ASA. Madison, USA.

Kopp, L.K. and K. Guillard. 2002. Clipping management and nitrogen fertilization of turfgrass: growth, nitrogen utilization and quality. Crop Sci. 42(4): 1225-1231. 
Krogman, K.K. 1967. Evapotranspiration by irrigated grass as related to fertilizer. Can. J. Plant Sci. 47(3): 281-287.

Meyer, J.L. and V.A. Gibeault. 1986. Turfgrass performance under reduced irrigation. California Agriculture 40(7): 1920.

Qian, Y.L. andM.C. Engelke. 1999. Performance of five turfgrasses under linear gradient irrigation. Hort Science34(5): 893-896.

Romero, C.C. and M.D. Dukes. 2009. Turfgrass and ornamental plant evapotranspiration and crop coefficient literature review, http://abe.ufl.edu/mdukes/pdf/turfgrass/TurfgrassFinal-Review.pdf (Accessed February 10, 2012).

Shearman, R.C. and J.B. Beard. 1973. Environmental and cultural preconditioning effects on the water use rate of
Agrostis palustris Huds., cultivar Penncross. Crop Sci. 13(4): 424-427.

Singh, Y., S.S. Rao and P.L. Regar. 2010. Deficit irrigation and nitrogen effects on seed cotton yield, water productivity and yield response factor in shallow soils of semi-arid environment. Agric. Water Manage. 97: 965-970.

Sills, M.J. and R.N. Carrow. 1983. Turfgrass growth, N use, and water use under soil compaction and $\mathrm{N}$ fertilization. Agron.J. 75(3): 488-492.

Wehner, D.J. and T.L. Watschke. 1984. Heat stress effects on protein synthesis and exosmosis of cell solutes in three turfgrass species. Agron.J. 76:16-19. 